\title{
The Effects of Elective Courses on the Personal Development of Prospective Teachers
}

\author{
Muzeyyen Altunbay \\ Education Faculty, Giresun University, Turkey
}

Copyright $(2018$ by authors, all rights reserved. Authors agree that this article remains permanently open access under the terms of the Creative Commons Attribution License 4.0 International License

\begin{abstract}
This study was conducted to determine the contribution of the elective courses, which were selected by the students themselves, to students' personal development during their undergraduate education. The study was carried out with 51 senior students studying at Faculty of Education, Turkish Education Department at Giresun University in Turkey. The research was carried out using a cross-sectional survey model as one of the qualitative research methods. A questionnaire was used as a data collection tool, consisting of multiple-choice and open-ended questions. In the analysis of the data, firstly frequency analysis for multiple choice questions was utilized and then it was presented by showing the percentage and frequency values on the table In the evaluation of open-ended questions, content analysis was used. The results gathered in the analysis of the data have been shown in graphs and tables for both visualization and for a more objective presentation. As a result, it is seen that it is common among the students that the number of elective courses is adequate for students, but that some courses cannot be selected by the students because of quota restrictions and that the elective courses should support the cultural development of the students and that the majority of the elective courses are not interdisciplinary. Also, almost 50 of these students thought that these courses do not contribute to their intellectual development at all. It is believed that the achieved results are expected to contribute to the teaching staff, especially to university administrators, in terms of reflecting the expectations and beliefs of the students on the creation and implementation of new elective courses in the restructured undergraduate programs.
\end{abstract}

Keywords Elective Course, Turkish Education, Self-improvement, Higher Education

\section{Introduction}

Higher education, which can be studied only after passing a national exam after compulsory education, includes a structure in which man can get specialized in a variety of fields, and also can continue it in a graduate program. The main objectives of higher education are clearly stated in the Higher Education Law No. 2547. Among them, paragraph 7 is significant in terms of clarifying the expectations of the society from the individuals "As Higher education institutions, being an important member of this Science World is to contribute to universal and contemporary development by carrying out scientific research and studies, producing information and technology, disseminating scientific data, supporting the development of the nation and collaborating with domestic and foreign institutions," [16]

It is clear that progress is possible only with the development and change. It is important to train the prospective teachers well, who are guides, pioneers, and intellectuals in the development of a community, to have better future generations. The change in education faculty graduate programs in 2007 was aimed to educate teachers better, and to keep up with progress in the world since they have a direct impact on the future of society. The most significant change in these programs has been in the course content and the introduction of the courses. "One of the most important features of the New Programs is the increase in the number of general culture courses. The aim of this change is to provide the teachers with the intellectual equipment which each teacher candidate should have if s/he is raised at university level" [18]. General culture courses and elective courses were added to the programs considering that they are going to be effective both for being an intellectual and equipped individual and for building good generations. Recent changes in 2018 are the inevitable results for the same purpose today.

Elective courses are preferred by students for various reasons beside the compulsory courses. The reasons for this are explained by Kutlu et al. [7] as follows:

The course method, course schedule, teaching staff, friends, impact of the person who had the course before, relationship with the instructors in everyday life, lecturer's teaching style, homework and project within the course, the 
classroom, the preference of the friends, the practicality of the course in real life, time, the number of people choosing the course, the evaluation of the course (examination), distribution of the documents prepared by the teaching staff to the students, attendance, the grade to pass the course in the past terms.

As seen, there are many reasons in the preference of the elective courses such as students, the course and the teaching staff. It is seen that in the literature, studies focused on elective courses are generally aimed at determining program evaluation, teaching member, teacher or student opinions. Some of these studies are about primary education such as Pamuk, Kiraz [11], Karagözoğlu [5], Meydan [8], Ceran, Karabacak [1], Dalkıran, Tuncel [2] etc. and some of them are about the elective courses in higher education such as Ökmen, Erdemir, Tekin [9], Kurnaz, Alev [6], Gülmez, Potur, Kayıhan [13], Demir [3], Demir, Ok [4] etc.

\section{The Elective Courses in Turkish Language Teaching}

As a result of the restructuring process initiated in the education faculties with the no. 97.39.2761, dated 04.11.1997 by the Council of Higher Education, teacher training programs which were implemented in the 1998-1999 education year were restructured in 2007 because of the recent change in the primary education programs by the Ministry of National Education in order to be implemented as the scientific and technological developments in the world by the 2003-2004 education year, and the last changes were made in 2018. Because the participant students are included in the undergraduate program that has been in use since 2007 , this program is the basis of this study, and also in order to make comparisons in terms of "elective courses", the 2018 program has been utilized.

Along with many changes in the previous program, one of the most important changes in Turkish Language Teaching Undergraduate Program in 2007 is the increase in flexibility in the fixed courses and in the number of elective courses. In the program, "The introduction of fixed courses in the teacher training programs is stretched; the faculty members had rights to determine courses up to $25 \%$ of the total credits in a program, and the number of elective courses has been increased. Due to the high number of core courses in some programs, the number of elective courses has been lesser [18]. It is also added that the elective courses can differentiate in various fields. However, while introducing the elective courses, it is suggested that students can take courses from other fields by stating that the elective courses in the program must be approved by the relevant members and approved by the faculty board. Elective courses may be specified as one or more courses according to the interests of the students and the teaching staff of the faculty. It is also suggested that elective courses should be introduced in order to gain professional ethics in teacher education programs in Europe and in America. Nevertheless, considering the available facilities, lack of teaching staff etc. it is often seen that not only the students can take elective courses from different faculties, but also they cannot get them from a different department in the same faculty. This leads students to get elective courses only related to their field, and maybe causes the capabilities increasingly disappear.

Elective courses in the Turkish education undergraduate program can be grouped in 3 different fields like A (Field and training courses), MB (Teaching courses) and GK (General culture courses). The distribution of elective courses in Turkish language education undergraduate program in 2007-2008 education year is presented in Table 1 (see Table 1)

Table 1. The distribution of elective courses in Turkish language education undergraduate program in 2007-2008 education year

\begin{tabular}{ccccccccc}
\hline & Field and training courses & \multicolumn{2}{c}{ Teaching courses } & \multicolumn{2}{c}{ General culture courses } & \\
\cline { 2 - 7 } & $\begin{array}{c}\text { The group of } \\
\text { must courses }\end{array}$ & $\begin{array}{c}\text { The group of } \\
\text { elective } \\
\text { courses }\end{array}$ & $\begin{array}{c}\text { The group of } \\
\text { must courses }\end{array}$ & $\begin{array}{c}\text { The group } \\
\text { of elective } \\
\text { courses }\end{array}$ & $\begin{array}{c}\text { The group of } \\
\text { must } \\
\text { courses }\end{array}$ & $\begin{array}{c}\text { The group } \\
\text { of elective } \\
\text { courses }\end{array}$ & $\begin{array}{c}\text { Total } \\
\text { number of } \\
\text { must } \\
\text { courses }\end{array}$ & $\begin{array}{c}\text { Total } \\
\text { number } \\
\text { of elective } \\
\text { courses }\end{array}$ \\
\hline $\mathbf{2 0 0 7}$ & 30 & 2 & 12 & - & 12 & 2 & 54 & 4 \\
\hline $\mathbf{2 0 1 8}$ & 28 & 6 & 16 & 6 & 8 & 4 & 52 & 16 \\
\hline
\end{tabular}

As seen in Table 1, in the 2018 program, the number of must courses in the field \&training courses and general culture curses has been decreased and elective courses have been increased. On the other hand, the number of elective courses as well as must courses in teaching courses has been increased. While there are 4 separate elective course groups from all three groups in the 2007 program, there are a total of 16 elective course groups in the 2018 program [19].

It can be stated that increasing the number of elective courses is an important step in addressing students with different interests and understanding the importance of interdisciplinarity in the changing world. The elective courses offered in the last four year in the Turkish Education Department, Department of Turkish and Social Sciences Education, Faculty of Education, Giresun University of Education, and their distribution are shown in Table 2 (see Table 2). 
Table 2. The elective courses offered in the Turkish Education Department during the undergraduate program

\begin{tabular}{cccccc}
\hline Elective Courses & Grade & Term & Elective Courses & Grade & Term \\
\hline Women's Education and Family Life & 1. grade & 1. term & Contemporary Turkish Literature & 4. grade & 8. term \\
\hline Social Gender Equality & 1. grade & 1. term & Novel Review & 4. grade & 8. term \\
\hline $\begin{array}{c}\text { Business Ethics and Values } \\
\text { Education }\end{array}$ & 1. grade & 1. term & Turkish Folk Poetry & 4. grade & 8. term \\
\hline $\begin{array}{c}\text { Turkish Language and Literature } \\
\text { Education }\end{array}$ & 2. grade & 3. term & Cinema and Literature & 4. grade & 8. term \\
\hline Leading Artists in Turkish Literature & 2. grade & 3. term & Turkish Literature & 4. grade & 8. term \\
\hline Oral Written Culture & 2. grade & 3. term & Story Review & 4. grade & 8. term \\
\hline Folklore & 4. grade & 7. term & Game Critique & 4. grade & 8. term \\
\hline Poetry Review & 4. grade & 7. term & Scientific Writing Techniques & 4. grade & 8. term \\
\hline Children's Folklore & 4. grade & 7. term & & &
\end{tabular}

As in Table 2, elective courses in the undergraduate program in 2007 are offered in the 1st, 3rd, 7th and 8th terms and are mainly composed of elective courses for field education. Courses are mainly taught by the instructors at the department. The elective courses offered by the instructors working at the other departments are "Women's Education and Family Life, Social Gender Equality and Business Ethics and Values Education", and they are taught electively in the first term of the first year.

\section{Statement of the Problem}

The Competencies Framework, which was designed for the higher education in Bergen (Norway) in May 2005, is defined as learning outcomes that must be achieved at the end of each level of tertiary education in order to enable individuals to adapt to the changing world. The main purpose of this framework is to improve individuals regardless of that whether they are taught formally or non-formally in an educational setting, and that they are able to adapt to the needs of the present [14].

The priority of each undergraduate program in higher education is to ensure that as well as personally and intellectually well equipped, individuals are well-trained in their fields / branches. Thus, the paragraph 7 of article 4 in the Higher Education Law No. 2547 also points to this situation. "Educating a citizen having knowledge, skills, attitudes and general culture of a profession, and also meeting the needs of the country along with their interests and talents by providing their own livelihood and happiness [16]. In this context, while the "must courses" in the undergraduate programs determined by YÖK affect the individuals' own professional skills and field knowledge, it is expected that the elective courses will affect the general culture and personal development of them. Otherwise, it is unexpected that they can be qualified enough to respond to the development and needs of the country even though they are graduated. Hence, the main problem of this study can be summarized as follows: "Have the elective courses in the field of Turkish language education any effect on the personal development of students?"

\section{The Aim of the Study}

This study was carried out in order to determine the contribution of elective courses to the personal and intellectual development of the students during their undergraduate education. In this context, the following questions were tried to be answered:

1. What are the main reasons affecting students' preferences while selecting the elective courses?

2. What are the opinions of the students about how elective courses should be organized?

3. Do the students think that elective courses contribute to their personal development?

4. Which core competencies / skills of the students have been developed thanks to the elective courses?

\section{Limitations}

The limitations of this study are as follows:

1. The study is limited to 4 th grade students studying at Turkish Education Department/ Turkish and Social Sciences Education Department in Faculty of Education, Giresun University.

2. The study is limited to the elective courses offered to students during their four-year training.

3. Research findings are limited to the data gathered by the data collection tool.

\section{The Method}

This study was carried out by using the cross-sectional survey model of qualitative research methods. The screening model is defined by Özdemir [10] as "a descriptive research method aiming to define the structure and characteristics of objects, societies, institutions, events". In a cross-sectional survey, the data collection process is carried out at one sitting.

\section{The Sample}

This research was conducted with a total of 51 students 
studying in the 4th grade of Turkish Education Department of Turkish Education and Social Sciences Education Department at Giresun University in Turkey. The age range of the students is 22.8 and the gender distribution is shown in Graph 1 (see Chart 1).

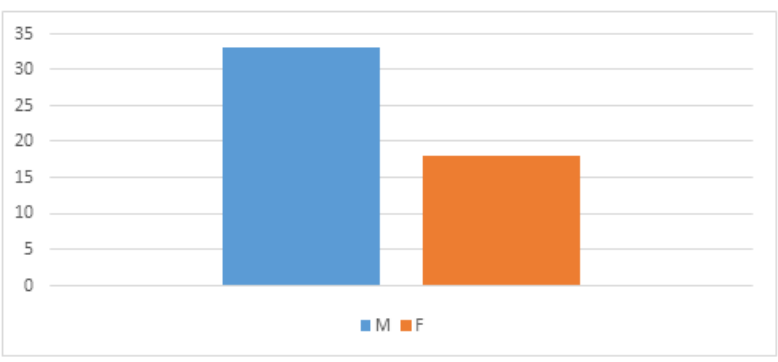

Chart 1. Distribution of students by gender

As shown in Chart 1, 33 of the students are male and 18 are female. The reason for choosing the sample among the senior students is that they have more elective courses than the other students (compared to the first, second and third classes).

\section{Data Collection Tool}

As a data collection tool, a questionnaire consisting of multiple-choice and open-ended questions was prepared. The questionnaire was sent to two field specialists to be reviewed and was conducted voluntarily in its final form.

\section{Data Analysis}

The analysis of the data was done in two ways: Firstly, frequency analysis for multiple choice questions was done and the data was presented on a table showing the percentage and frequency values. Secondly, content analysis was conducted for open-ended questions. So, open-ended questions were first coded by the researcher, and then analyzed and interpreted.

\section{Findings and Suggestions}

In this section, the findings of the research are analyzed and the results obtained from the data are shown in graphs and tables for both visualization and for a more objective presentation.

Before explaining the effect of the elective courses on the personal and intellectual development of the students, the reasons for choosing the elective courses should be stated. The reasons why students prefer elective courses they have taken during their four year undergraduate education are shown in Graph 2 (see Chart 2).

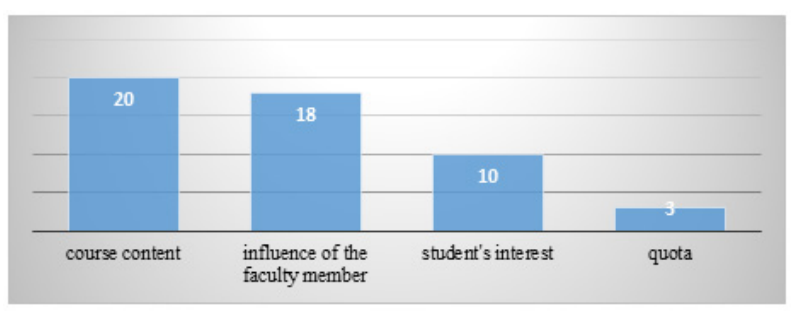

Chart 2. Reasons for elective courses

As can be understood from Chart 2, the reasons for the selection of courses can be evaluated in four categories. The content of the course, the influence of the instructor, the student's interest and the quota. It is seen that the content of the course is the most important factor affecting the choice of the course. That's why, the fact that students are informed about the content of their elective courses will directly influence their choice. At this point, it is necessary to update / renew the course information (course objectives, content, learning outcomes, evaluation criteria, weekly course plan, etc.) in the course information packs / course hand-outs.

It is clear that the influence of the instructor is the second most important factor in the preference of the students. This factor is mostly evaluated by students, such as the title of the instructor, their relation with the student, evaluation criteria. As well as being not too influential on elections, the interest of the learner is not very decisive on them too. This is probably caused by the fact that they are the field elective courses. It can be said that the 'interest' factor is not influential on these elections since the students cannot take the elective courses from other departments or faculties.

It is understood that although the quota is not a decisive issue, it has an effect on the elections. This factor is not very decisive in the choice of course and is considered as a negative factor in the fact that the desired course cannot be selected. The students were asked if they thought that the number of elective courses were enough during their undergraduate education, and whether there was any course they could not choose although they would like to study one. The answers were shown in Chart 3 (see Chart 3).

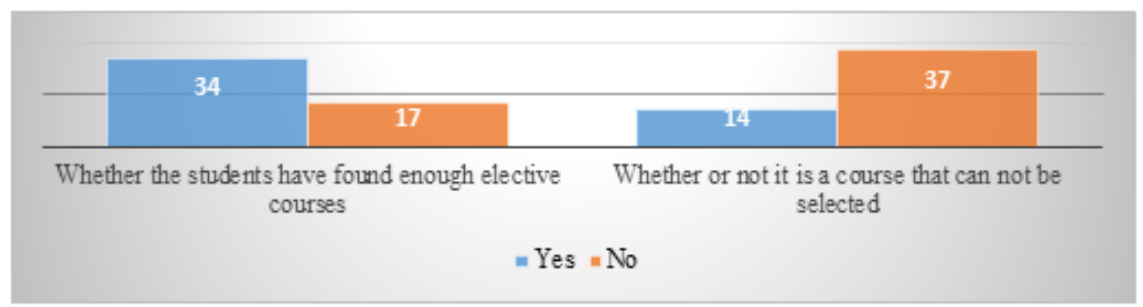

Chart 3. The opinion of the students on elective courses 
When Chart 3 is examined, it is found out that 34 of the students think that the number of elective courses is sufficient, whereas 17 of them do not find it enough. In addition, 14 students stated that they could not choose the course they wanted. 14 students stated that the main reason for not choosing the course they wanted is the "quota" problem. The question of how the elective courses should be organized is asked to the students and the answers are shown in Table 3 (see Table 3 ).

Table 3. The opinion of the students on the arrangement of elective courses

\begin{tabular}{cc}
\hline The opinions & $\begin{array}{c}\text { The number } \\
\text { of the } \\
\text { students (n) }\end{array}$ \\
\hline They should support cultural development. & 13 \\
\hline $\begin{array}{c}\text { They should be offered according to the interests } \\
\text { of students along with the demand. }\end{array}$ & 9 \\
\hline There should be too many courses. & 7 \\
\hline They should include current topics. & 5 \\
\hline They should be practical instead of theoretical. & 4 \\
\hline They should be about the profession/field. & 4 \\
\hline $\begin{array}{c}\text { They should be appropriate to the examination } \\
\text { system (KPSS) }\end{array}$ & 3 \\
\hline Their credit shouldn't be too much. & 2 \\
\hline There shouldn't be any quota problem. & 2 \\
\hline $\begin{array}{c}\text { They should be selected from any faculty or } \\
\text { department. }\end{array}$ & 1 \\
\hline $\begin{array}{c}\text { There shouldn't be too many elective courses in } \\
\text { the final semester, there should be a balanced } \\
\text { distribution among the semesters }\end{array}$ & 1 \\
\hline Total \\
\hline
\end{tabular}

As can be seen in Table 3, the students' opinions on how to organize elective courses differentiate from each other. The fact that elective courses have the content to "support cultural development" is the first among the options. This option is followed by many other options such as interest, be numerous, containing up-to-date information, based on practice, credit, choosing from other faculties or departments, quota limitations etc.

21 students answered Yes and 30 students answered No to the question whether there was an elective course that could be evaluated interdisciplinary. Therefore, more than half of the students stated that there is no interdisciplinarity in elective courses. It was asked to the students whether the elective courses had any contribution on their intellectual development and the responses are shown in Graph 4 (see Chart 4).

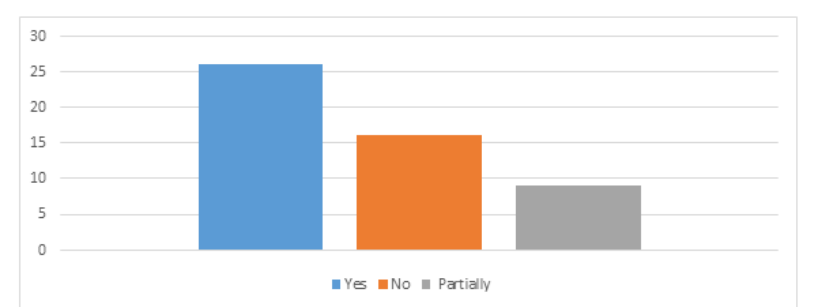

Chart 4. Whether the elective courses contribute to the intellectual development of the students or not
As stated in Chart 4, 26 students said that elective courses contributed to their intellectual development, 9 of them stated that they contributed to them partially differently from the must courses, and 16 students said that elective courses did not contribute to their intellectual development in any way.

The students asked if they had the opportunity to choose which courses they would take and which department these courses belong to. The answers were shown together with the frequency analysis in Table 4 (see Table 4).

Table 4. Elective courses that the students would like to select

\begin{tabular}{cc}
\hline Course/Department & The number of the students (n) \\
\hline Law & 12 \\
\hline Physical Education & 7 \\
\hline Psychology & 4 \\
\hline Mathematics & 4 \\
\hline History & 4 \\
\hline Web Design & 4 \\
\hline Games and the Children & 3 \\
\hline Citizenship & 3 \\
\hline Music & 3 \\
\hline Medicine & 2 \\
\hline Sociology & 1 \\
\hline Art & 1 \\
\hline Geography & 1 \\
\hline English & 1 \\
\hline Cinema and Acting & 1 \\
\hline Total & 51 \\
\hline & \\
\hline
\end{tabular}

According to Table 4, the law course is the most preferred one and it is followed by Physical Education, Psychology, Mathematics, History, Web Design, Games and Children, Citizenship, Music, Medicine, Sociology, Art, Geography, English and Cinema and Acting. In particular, it has been determined that physical education, music, art, cinema and the acting are directly related to the student's ability, and that the other courses are fields of special interest.

A question was asked to the students who expressed their positive opinions that is "which basic competency / skill was contributed to the most by the elective courses", and the students were not under pressure while answering. The responses were shown in Table 5 (see Table 5).

Table 5. Contribution of elective courses to students' basic competencies / skills

\begin{tabular}{cccc}
\hline Basic Skills & Female(n) & Male(n) & Total(n) \\
\hline $\begin{array}{c}\text { Correct and Effective } \\
\text { Use of Turkish }\end{array}$ & 15 & 18 & 32 \\
\hline Communication & 12 & 17 & 29 \\
\hline Creative Thinking & 12 & 12 & 24 \\
\hline Critical Thinking & 9 & 13 & 22 \\
\hline Research & 5 & 8 & 13 \\
\hline Entrepreneurship & 7 & 5 & 12 \\
\hline $\begin{array}{c}\text { Using Information } \\
\text { Technology }\end{array}$ & 5 & 5 & 10 \\
\hline Making Decision & 3 & 6 & 9 \\
\hline Problem Solving & 4 & 3 & 6 \\
\hline
\end{tabular}


When Table 5 is reviewed, it is seen that the elective courses affect the basic skill of "Correct and Effective Use of Turkish" the most. For the Turkish Language Department, this is an expected outcome, and it is followed by communication, creative thinking, critical thinking, and research, entrepreneurship, using information technology, decision making and problem solving.

Basic skills taught in the Elementary Turkish Language Teaching Program in 2006 can be described as the basic characteristic competencies which an ideal human being should have in the 21 st century. In order to educate a citizen having knowledge, skills, attitudes and general culture of a profession, and also meeting the needs of the country along with their interests and talents by providing their own livelihood and happiness as in Higher Education Law, the courses which will contribute to students' entrepreneurship, communication skill and using information technology skills etc. should be offered. It is also important that these courses include entrepreneurship, communication skill and using information technology skills etc which are expected in an individual in the $21 \mathrm{st}$ century. The acquisition of these basic skills depends on the content of the lesson, the teaching materials and the methods and techniques used in the class.

\section{The Result, Discussion and Suggestion}

The results of this research carried out with a total of 51 students studying in in the 4th grade of Turkish Education Department of Turkish Education and Social Sciences Education Department at Giresun University have been evaluated by the students in terms of whether their elective courses contribute to their personal skills. The data were evaluated and interpreted by frequency analysis and content analysis in the study in which the scanning model was used.

It was found out in the study that the most important factor determining the preferences of the students was the content of the course, which is followed by the instructor factor. This result matches up with the findings of the research by Uçgun [12] conducted to identify the reasons affecting the preferences of Turkish teacher candidates on elective courses. Uçgun has reached the conclusion that the students have decided by considering the grading system of their personal abilities, instructors, and friends [12].

The option the course content, which is taken too seriously by the students indicates that the course / information package needs to be regularly renewed / activated. It is believed that due to being the field/department courses, the elective courses cause the quotas and interest to be less effective on course selection.

Shortly, it was found out that the students thought that the number of elective courses is sufficient, but due to quota restrictions, some courses could not be selected by the students (see Chart 3). It is stated in the article 13-14 Giresun University Associate or Bachelor Education and Examination Regulation that the number of students enrolled in elective courses must be at least ten, if the number of students enrolled in these courses is less than ten, the commission must decide upon whether to offer the course [15]. Therefore, the quota limitation causes some students not to get the course they would like to have so that there wouldn't be too crowded classes.

It is found out that the idea of 'the courses should support cultural development' has been seen more important than the others. This view can be interpreted as the students' desire to take elective courses, not from their field/department, but from other fields/departments. This option is followed by relevance to the area of interest, being in high number, including current topics, practical rather than theory, etc. (see Table 3). This data, which is the expression of the students about how the elective courses should be organized, is important in terms of guiding the instructor in the preparation and implementation stages of the courses. The result of the study conducted by (2016) shows that the elective courses contribute the students' multi-faced development. Moreover, the study by Demir [3], which is also carried out to determine the instructors' and students' opinion on elective courses, found that the content of the elective courses should be up to date, the quota should not be limited, the courses should address all students, the professional branches should be taught and they should get the students' interest. The fact that the results of this study are parallel to Demir's research results is important because it shows that there is not much change in the implementation of the elective courses in the class and the experienced problems [3].

According to the results of the research, 30 students stated that the elective courses are not interdisciplinary, and 16 of the students also pointed out that these courses do not contribute to their intellectual development; however, 9 students expressed the electives contributed partly, and 26 students expressed that the elective courses they received had positive effects on their intellectual and personal development (see Chart 4).

It is asked the students which elective course they would choose if they had the opportunity, and the answer was determined as the "law" course the most. This course is followed by physical education, psychology, mathematics, web design, history, etc. "(see Table 4). It is understood that these elective courses have the most positive effect on the basic skills of "correct, and effective use of Turkish", followed by communication and other options. As known, the ability to communicate effectively and to use the language correctly is one of the most important requirements of socialization. However, Ökmen et al. found that there was no difference among the students who took elective courses in terms of socialization and that elective courses did not have any positive effect on the socialization of the students who participated in the 
research. Still, it should be taken into consideration that there is difference between this study and Ökmen et al. in terms of the students, departments and courses [9].

\section{About the Result of the Research}

1. Elective courses should be organized in such a way that students will be able to take courses from different faculties or departments. (In addition to the increase in the number of elective courses, which is a positive development, in the newly published 2018 Undergraduate Program, these elective courses are mainly theoretical, so the new elective courses should be offered for the students who study in the fields of art, music, physical education, and in that way their skills must be improved.

2. If there is more than one elective course in the same group, they should not be on the same day and hour in the program. The student who cannot choose the course due to the quota limitation should be able to attend the course on another different day and time.

3. The elective courses shouldn't be theoretical based, but there should be practical elective courses as well.

4. The students should be informed about all the elective courses in the registration day by their supervisors.

5. The content of the elective courses should be updated, the interdisciplinarity should be emphasized.

Increasing the number of elective courses especially in universities or faculties, where social and artistic activities are limited, will contribute to the development of multi-faceted and enlightened individuals who can fulfill the requirements of contemporary education.

\section{REFERENCES}

[1] Ceran, D. \& Karabacak, E (2013). Okuma Becerileri Seçmeli Dersine Yönelik Öğretmen Görüşlerinin Değerlendirilmesi. The Journal of Academic Social Science Studies. 6 (7): 247-275.

[2] Dalkıran, O. \& Tuncel, F. (2007). Ortaöğretim Kurumlarında Beden Eğitimi Dersinin Seçmeli Ders Olarak İşlenmesinin Öğrenciler Gözüyle Değerlendirilmesi. Spormetre Beden Eğitimi ve Spor Bilimleri Dergisi, 1: $37-42$.

[3] Demir, A. (1996). Üniversitedeki Seçmeli Ders Uygulamasının Öğrenciler ve Öğretim Üyelerince Değerlendirilmesi, Psikolojik Danışma ve Rehberlik Dergisi, 2(7): 24-31.

[4] Demir, A. \& Ok, A. (1996). Orta Doğu Teknik
Üniversitesindeki Öğretim Üye ve Öğrencilerinin Seçmeli Dersler Hakkındaki Görüşleri, Hacettepe Üniversitesi Eğitim Fakültesi Dergisi 12: 121-125.

[5] Karagözoğlu, N. (2015). Ortaokul 5. Sinıflarda Tercih Edilen Seçmeli Dersler ve Tercih Nedenlerinin Öğrenci ve Veli Görüşlerine Göre Değerlendirilmesi. Pegem Eğitim ve Ögretim Dergisi, 5(1): 69-94.

[6] Kurnaz, M. \& Alev, N. (2009). İlköğretim ve Ortaöğretim Lisansüstü Öğrencilerinin Ders Seçimi Yaklaşımları ve İlgili Sorunları, Türk Fen Ĕgitimi Dergisi, 6 (3): 38-52.

[7] Kutlu, B. S. \& Abalı, Y. A.\& Eren, T. (2012): Çok Ölçütlü Karar Verme Yöntemleri İle Seçmeli Ders Seçimi. Sosyal Bilimler Dergisi, 2 (2): 5-25.

[8] Meydan, H. (2015). Din, Ahlak ve Değerler Alanı Seçmeli Derslerinde Karşılaşılan Problemler (Öğretmen Görüşlerine Dayalı Nitel Bir Araştırma). Turkish Studies. 10 (3): 673-694.

[9] Ökmen, A. S. \& Erdemir, İ \& Tekin, H. A. (2009). Beden Eğitimi, Resim ve Müzik Seçmeli Dersi Alan Öğrencilerin Toplumsallaşma Düzeylerinin Karşılaştırılması. Balıkesir Üniversitesi Sosyal Bilimler Enstitüsü Dergisi, 12 ( 21): 1-6.

[10] Özdemir, E. (2015). “Tarama Yöntemi”. Kuramdan Uygulamaya Ĕ̈itimde Bilimsel Araştırma Yöntemleri (Ed. Muhsin Metin). Ankara: Pegem Yayınc1lık.

[11] Pamuk, E. \& Kiraz, Z. (2016). Ortaokullarda Okutulan Seçmeli Ders Uygulamalarında Okul Yöneticilerinin Karşılaştıkları Problemler. Abant İzzet Baysal Üniversitesi Eğitim Fakültesi Dergisi, 16 (3): 977-1003.

[12] Uçgun, D. (2012). Türkçe Öğretmeni Adaylarının Seçmeli Ders Tercihlerini Etkileyen Etmenler, Journal of Human Sciences [Online]. (9)2: 1337-1349.

[13] Ünsal Gülmez, N. \& Ayyıldız Potur, A.; Kayıhan, K. S. (2016). Mimarlık Eğitiminde Seçmeli Dersler: Çeşitlilik, Esneklik, Kısitlar ve Olanaklar Üzerine, Mimarlık Dergisi, 52 (388): 49-53.

[14] http://www.yok.gov.tr/web/uluslararasi-iliskiler/86 erişim [11.07.2018]

[15] http://mevzuat.basbakanlik.gov.tr/Metin.Aspx?MevzuatKo $\mathrm{d}=8.5 .15197 \&$ MevzuatIliski $=0 \&$ sourceXmlSearch $=$ erişim [11.07.2018]

[16] http://www.yok.gov.tr/documents/10348274/10733291/3.1 .1. $++2547+$ say $\%$ C $4 \%$ B $11 \% \mathrm{C} 4 \% \mathrm{~B} 1 \% 20 \mathrm{Y} \% \mathrm{C} 3 \% \mathrm{BCksek} \%$ C3\%B6\%C4\%9Fretim+Kanunu/58c65947-cbc1-4b3e-878 5-b268ce65d3ab date of access [11.07.2018]

[17] http://www.yok.gov.tr/documents/10279/49665/aciklama programlar/aa7bd091-9328-4df7-aafa-2b99edb6872f date of access [11.07.2018]

[18] http://www.yok.gov.tr/documents/10279/30217/E\%C4\%9 $\mathrm{E} \% \mathrm{C} 4 \% \mathrm{~B} 0 \mathrm{~T} \% \mathrm{C} 4 \% \mathrm{~B} 0 \mathrm{M}+\mathrm{FAK} \% \mathrm{C} 3 \% 9 \mathrm{CLTES} \% \mathrm{C} 4 \% \mathrm{~B} 0$ $\% 20 \%$ C3\%96\%C4\%9ERETMEN+YET\%C4\%B0\%C5\%9 ET\%C4\%B0RME+L\%C4\%B0SANS+PROGRAMLARI.p df/054dfc9e-a753-42e6-a8ad-674180d6e382 date of access [11.07.2018]

[19] http://www.yok.gov.tr/documents/10279/41805112/Turkce Ogretmenligi_Lisans_Programi.pdf date of access [11.07.2018] 